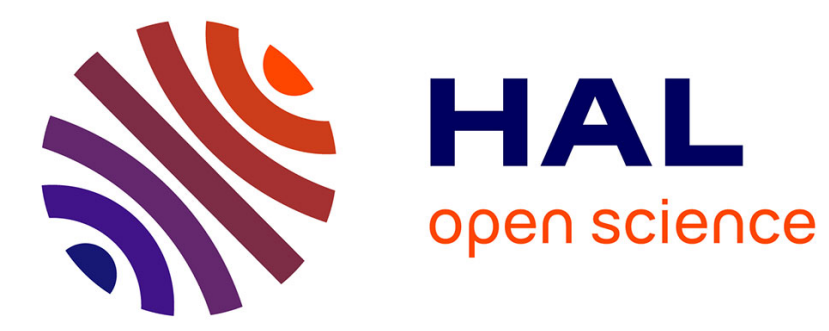

\title{
Doing urban geography in South Africa
}

Neil Dewar, Denise Pumain

\section{To cite this version:}

Neil Dewar, Denise Pumain. Doing urban geography in South Africa. Environment and Planning A, 1996, 4 (28), pp.603-605. 10.1068/a280603 . halshs-01625364

\section{HAL Id: halshs-01625364 https://shs.hal.science/halshs-01625364}

Submitted on 27 Oct 2017

HAL is a multi-disciplinary open access archive for the deposit and dissemination of scientific research documents, whether they are published or not. The documents may come from teaching and research institutions in France or abroad, or from public or private research centers.
L'archive ouverte pluridisciplinaire HAL, est destinée au dépôt et à la diffusion de documents scientifiques de niveau recherche, publiés ou non, émanant des établissements d'enseignement et de recherche français ou étrangers, des laboratoires publics ou privés. 
Commentary

\section{Doing urban geography in South Africa}

"Johannesbourg est la vraie capitale de l'Union, celle où l'on sent le mieux vivre son âme, celle qui incarne le mieux son idéal. Cape Town, allongée autour de sa vaste baie, étendue au pied des escarpements de la Montagne de la Table, sourit trop mollement, sous un ciel trop doux. Durban est trop britannique et trop joyeuse, et trop orientale aussi, avec sa population d'Hindous et son port tourné vers la mystérieuse Asie; Prétoria est trop officielle, administrative et somnolente, et Bloemfontein trop chauvinement 'Vieux Boer' et trop fermière."

Jacques Weurlesse Noirs et Blancs 1931

Author:

Refererce?

A long time has passed since such poetic and cutting observations could be made by a Belgian geographer. The practice of urban geography has changed, as have urban realities. It is a time of fundamental transition in South Africa, from a society underpinned by the structures of apartheid toward a new nonracial and democratic dispensation. The consequences of such revolutionary change remain unpredictable, especially in the urban realm, which poses many urgent problems. The fact that space both reinforced and exacerbated social segregation suggests the potential role of geographers in the rebuilding of society, for example through local urban planning, contributing toward current debates about the redrawing of the administrative maps of the country, and in understanding modern urban dynamics.

"Structuring the Contemporary City" was the title of the last conference of the Commission on Urban Development and Urban Life of the International Geographical Union, held in Cape Town in August 1995. A week-long preconference field excursion, traversing the country from Johannesburg to Cape Town, afforded many of the overseas Commission members an early familiarization with the history and regional geography of South Africa, a necessary context for fully appreciating the circumstances of growth and change of the major urban centres. En route, two fullday urban field trips provided a highly focused and informative introduction to the morphology of the South African city, particular emphasis being placed upon the legacies of settler colonialism and the sociopolitical system that assumed the identity of 'apartheid'.

An innovative feature of the conference was a workshop which explored two issues that have particular import and immediacy in South Africa, given the context of a new political hegemony and constitutional order: namely, the issues of integration, segregation, and urban transformation. It seems worthwhile to summarize the themes of the debates which commanded the attention of an international community of urban geographers. This brief overview will be completed by recalling the research agenda issues which emerged from a recent review of the literature on urban South Africa (Lemon, 199\$), and by a frequency analysis of the main themes of urban research as they appear in a long list of references collected by Philippe Guillaume.

Workshop on urban social segregation

Small group sessions explored five separate themes relating to social segregation, integration, and urban transformation prior to reconvening for a full workshop debate. 
The themes were:

1 Definition and measurements: How do we define segregation and integration (socially and physically)? What are appropriate indicators? Is it possible to measure levels and change?

2 Causes of segregation and integration: What structural forces in society underlie contemporary manifestations of social segregation, and its change over time?

3 Trends in segregation and integration: Are manifestations of segregation likely to be permanent, or is there evidence to suggest that it may be declining and under what circumstances?

4 Positive and negative features of segregation: What social costs does segregation incur? What social problems does it generate? Are benefits to be gained and for whom? Does it contribute to a sense of cohesion? Is integration a desirable planning goal?

5 Planning influence and response: Does planning reinforce segregation? What planning strategies exist to reduce segregation or overcome the problems arising from it? The Commission's proceedings will be published and these will contain a record of the workshop's arguments and conclusions.

Some specific trends in South African urban geography

South African geographers at the conference contributed approximately twenty formal papers, which give some impressions of current research among the South African geographic community.

Urban geography in South Africa is predominantly political geography: analyses centred largely upon transformation of the post-Apartheid city. Current research involved local authority restructuring, demarcation of metropolitan and municipal boundaries, and the implications of the relative powers conferred upon each in terms of land, group autonomy, ownership, and the provision of public amenities and facilities. Much of this polemic turned upon the issue of redressing the political, social, and economic inequities of the past. Indeed social justice appeared as a leitmotiv in the discourse (Smith, 1992). Other research initiatives were directed toward: understanding state policy toward urban Africans; African population movement and informal settlement-the occupation of land by recent or temporary in-migrants, many of them foreigners or clandestine, whose future is uncertain; evolving black homeownership patterns; local initiatives for urban economic development; location patterns of minority groups and community integration; segregation, integration, and the sustainable city; urban environmental quality.

Prominent too, were studies of informal settlements. At a conference of the Society of South African Geographers in July, eleven sessions under the rubric "Informal settlements" appeared in the programme. Themes included housing; social dynamics; power relations and the state; service provision; upgrading initiatives; management and planning; informal settlements and urban reconstruction; environmental issues; comparative perspectives; government and the informal sector; and research agendas. Themes in other urban-related sessions included post-Apartheid cities; the sustainable city; Southern African land issues; local economic development; sports and leisure; and urbanization. A plenary address focused upon "Social justice in the new South Africa".

Elsewhere, in a much more documented review, of the contribution of urban geographers to the study of South African cities, A..... Lemon (1995) identifies four main items in their research agenda: the processes and patterns of residential desegregation; informal settlement and urbanization; land, housing, and transport in post-Apartheid cities; service provision and the Apartheid inheritance.

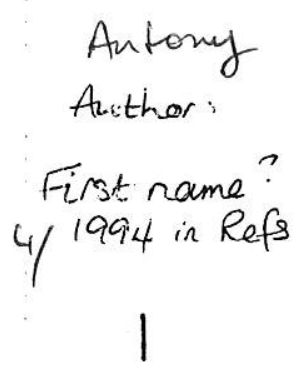


Experiences during the urban field excursions prompt other, more general, observations about issues that would appear to justify investigation but which have been neglected to date. There is little evidence of comparative social area analysis (except in the work of Christopher, 1994), perhaps because it is so obvious-the only country in the world where urban ecology could be discerned directly from air photographs or satellite images (Davies, 1981)! Particularly in the large cities there is a growing trend of black people, formerly compelled to reside in remote townships, to congregate under precarious circumstances in overpopulated housing in the inner city where jobs are located. A related issue is that of urban renewal and the restitution of land to communities whose 'normal' historical trajectory was traumatically disrupted by forced removals in terms of Apartheid planning. District Six in Cape Town and Cato Manor in Durban are highly visible and contentious examples of this challenge to urban planners and policymakers. Decentralization of the retail and office function from the central business district appears to be an accelerating process with far-reaching implications for the future form and functioning of the major metropolitan areas. One significant current debate involves the use of public open space in the context of long-term public amenity versus short-term housing priorities and the realities of land invasions by squatters. And, although research directed at particular issues has been conducted in a variety of towns and cities, there is an absence of more general comparative studies and analysis of urban systems at the regional or national scale (less than $5 \%$ in the Guillaume bibliography).

Conclusion constituls)

South Africa Appear today both a laboratory for urban research and as a place where social transformations involve many spatial consequences and urban planning issues. Can geographical knowledge be of value to help the desegregative process be a regular and safe transition instead of a chaotic or violent bifurcation? One obvious winning card of this country is the quality of the urban environment in large parts of the cities, and the broad diversity of towns and cities all over the territory. The evidene enthusiasm and dedication of our South African colleagues as well as the relevance of their work are other assets to meet the challenge.

\section{N Dewar, D Pumain}

Acknowledgements. We would like to acknowledge the role of Professor Ron Davies, who organized in Cape Town the annual meeting of the Commission "Urban Development and Urban Life" of the IGU under the theme of "Structuring the Contemporary City: International Geographical Perspectives" (21-25 August 1995) and especially animated the workshop. We also would like to thank Philippe Guillaume for his kind communication of the quasi-exhaustive bibliography he collected about urban geography in South Africa.

\section{References}

Christopher A J, 1994 The Atlas of Apartheid (Routledge, London)

Davies R J, 1981, "The spatial formation of the South-African city" Geojournal 2 59-72 Lemon A (Ed.), 1994 The Geography of Change in South Africa (Belhaven, London) Smith D M (Ed.), 1992 The Apartheid City and Beyond: Urbanization and Social Change in South Africa (Routledge and Witwaterstrand University Press, Johannesburg)

Author:
- 1995 in text 